\title{
Effects of exercise on myokine gene expression in horse skeletal muscles
}

\author{
Hyo Gun Lee ${ }^{1, a}$, Jae-Young Choi ${ }^{1, a}$, Jung-Woong Park ${ }^{1}$, Tae Sub Park ${ }^{2}$, Ki-Duk Song ${ }^{3}$, \\ Donghyun Shin ${ }^{3, *}$, and Byung-Wook Cho ${ }^{1, *}$
}

\author{
* Corresponding Authors: \\ Donghyun Shin \\ Tel: +82-63-270-4748, Fax: +82-63-270-2614, \\ E-mail: sdh1214@gmail.com \\ Byung-Wook Cho \\ Tel: +82-55-350-5515, Fax: +82-55-350-5519, \\ E-mail: bwcho@pusan.ac.kr \\ ${ }^{1}$ Department of Animal Science, College of Natural \\ Resources and Life Sciences, Pusan National \\ University, Miryang 50463, Korea \\ ${ }^{2}$ Graduate School of International Agricultural \\ Technology and Institute of Green-Bio Science and \\ Technology, Seoul National University, Pyeongchang \\ 25354, Korea \\ ${ }^{3}$ Department of Animal Biotechnology, Chonbuk \\ National, University, Jeonju 54896, Korea \\ a These authors contributed equally to this work.
}

ORCID

Hyo Gun Lee

https://orcid.org/0000-0002-3286-7368

Jae-Young Choi

https://orcid.org/0000-0001-8264-1482

Jung-Woong Park

https://orcid.org/0000-0003-0885-3078

Tae Sub Park

https://orcid.org/0000-0002-0372-5467

Ki-Duk Song

https://orcid.org/0000-0003-2827-0873

Donghyun Shin

https://orcid.org/0000-0002-0819-0553

Byung-Wook Cho

https://orcid.org/0000-0002-7739-1391

Submitted May 16, 2018; Revised Jul 23, 2018; Accepted Sept 13, 2018
Objective: To examine the regulatory effects of exercise on myokine expression in horse skeletal muscle cells, we compared the expression of several myokine genes (interleukin 6 [IL-6], IL-8, chemokine [C-X-C motif] ligand 2 [CXCL2], and chemokine [C-C motif] ligand 4 [CCL4]) after a single bout of exercise in horses. Furthermore, to establish in vitro systems for the validation of exercise effects, we cultured horse skeletal muscle cells and confirmed the expression of these genes after treatment with hydrogen peroxide.

Methods: The mRNA expression of $I L-6, I L-8, C X C L 2$, and CCL4 after exercise in skeletal muscle tissue was confirmed using quantitative-reverse transcriptase polymerase chain reactions (qRT-PCR). We then extracted horse muscle cells from the skeletal muscle tissue of a neonatal Thoroughbred. Myokine expression after hydrogen peroxide treatments was confirmed using qRT-PCR in horse skeletal muscle cells.

Results: $I L-6, I L-8, C X C L 2$, and CCL4 expression in Thoroughbred and Jeju horse skeletal muscles significantly increased after exercise. We stably maintained horse skeletal muscle cells in culture and confirmed the expression of the myogenic marker, myoblast determination protein $(M y o D)$. Moreover, myokine expression was validated using hydrogen peroxide $\left(\mathrm{H}_{2} \mathrm{O}_{2}\right)$ treated horse skeletal muscle cells. The patterns of myokine expression in muscle cells were found to be similar to those observed in skeletal muscle tissue.

Conclusion: We confirmed that several myokines involved in inflammation were induced by exercise in horse skeletal muscle tissue. In addition, we successfully cultured horse skeletal muscle cells and established an in vitro system to validate associated gene expression and function. This study will provide a valuable system for studying the function of exercise-related genes in the future.

Keywords: Exercise; Horse Skeletal Tissue; Horse Skeletal Muscle Cells; Myokine

\section{INTRODUCTION}

The horse is a valuable model animal for studying the effects of exercise, because it is the most adaptive animal for exercise among livestock. Thoroughbreds are one of the most famous horse breeds in the horse racing industry, and they were specially bred for speed, endurance, and strength from the early 1700s. Through the selection of these characteristics, Thoroughbred has become a horse for racing [1]. The exercise characteristics of Thoroughbred are used as a biological model in the field of exercise physiology, and helped identify the molecular mechanisms of the adaptive responses to exercise [2].

To date, a number of genes related to exercise have been screened through high throughput analyses such as RNA sequencing [3] or microarrays [4]. A number of differentially expressed genes from genomic studies have been studied for functions in the stress response [2,5] and validated in horse muscles [6-8] Exercise-induced stress is considered 
one of the major stimuli for the adaptation to and improvement of physical performance of racing horses. Exercise induces endoplasmic reticulum, oxidative, and inflammatory stresses in muscle. After muscles contract during exercise, skeletal muscles produce a group of cytokines called myokines (interleukin 6 [IL-6], interleukin 6 [IL-8], chemokine [C-C motif] ligand 4 [CCL4], and chemokine [C-X-C motif] ligand 2 [CXCL2]), which function in metabolism, insulin action, and inflammatory responses [9-13]. Among these, IL-6 is the first myokine to be secreted into circulation [14], and it acts as both a pro-inflammatory and an anti-inflammatory myokine. Plasma $I L-6$ was locally expressed in skeletal muscle without muscle damage, and its concentration dramatically increased following exercise [10]. To date, $I L-6$ is known to induce a variety of effects, including glucose and fat metabolism $[15,16]$ and anti-inflammatory functions during exercise [17]. IL-8 is a chemokine, which mainly functions in the chemotaxis of neutrophils. It is also expressed in skeletal muscle after exercise [11], and it has been hypothesized to play a role in angiogenesis within skeletal muscles [18]. After endurance racing in horses, CXCL2, also called macrophage inflammatory protein $2-\alpha(M I P 2-\alpha)$, is upregulated in peripheral blood mononuclear cells [4]. In humans, CXCL2 is significantly induced in exercising legs [19]. CCL4 is a chemoattractant for a variety of immune-related cells [20]. It is highly expressed in skeletal muscles in response to pathological situations [21], and the concentration of CCL4 increases following exercise [12]. It induces myoblast proliferation via G protein-coupled receptors, extracellular signal-regulated kinases $1 / 2$, and mitogen-activated protein kinase pathway, and it may be involved in wound healing after muscle injury $[22,23]$.

In this study, we examined the gene expression of myokines, including $I L-6, I L-8, C X C L 2$, and CCL4 in Thoroughbred and Jeju horse skeletal muscles before and after a single bout of exercise. Furthermore, we tested the myokine expression in primary muscle cells that were derived from Thoroughbred skeletal muscles in response to hydrogen peroxide $\left(\mathrm{H}_{2} \mathrm{O}_{2}\right)$ treatment, which mimics oxidative stress in vitro. The results of this study could be valuable for the establishment of strategies that manage exercise-induced muscle damage in the equine industry.

\section{MATERIALS AND METHODS}

\section{Study animals}

Six horses were used in this study, and they were divided into two groups: Thoroughbred and Jeju horses. The Pusan National University-Institutional Animal Care and Use Committee approved the study design (Approval Number: PNU-20150864).

\section{Tissue sampling}

Two stallions, one Thoroughbred mare, and three Jeju mares (aged 5 to 10 and weighing 500 to $700 \mathrm{~kg}$ ) were used to obtain skeletal muscle samples before and after exercise. Exercise involved trotting at $13 \mathrm{~km} / \mathrm{h}$ for $30 \mathrm{~min}$ and cantering through lunging and long-reining (circular bridge lunging). Skeletal muscle samples were collected from the triceps brachii of the right leg.

\section{Primary horse muscle cell culture}

A skeletal muscle tissue biopsy was performed on the leg of a neonatal Thoroughbred. Horse skeletal muscle cells were maintained and sub-passaged in Medium 199 (Gibco, Grand Island, NY, USA) supplemented with $10 \%$ fetal bovine serum (FBS; Invitrogen, Carlsbad, CA, USA), 2\% donor equine serum (DES; Hyclone, Carlsbad, CA, USA), and 1\% antibiotic-antimycotic (ABAM; Invitrogen, USA). Medium 199 supplemented with $0.5 \% \mathrm{FBS}$ and $1 \% \mathrm{ABAM}$ was used as the differentiation medium. Horse skeletal muscle cells were cultured in a humidified atmosphere with $5 \% \mathrm{CO}_{2}$ at $37^{\circ} \mathrm{C}$. At approximately $70 \%$ to $80 \%$ confluence, cells were treated with $1 \mathrm{mM} \mathrm{H}_{2} \mathrm{O}_{2}$ (Junsei, Tokyo, Japan) and cultured for 6 h. Cells were gently washed twice with phosphate-buffered saline, and were then harvested using 0.05\% trypsin-ethylenediaminetetraacetic acid (Welgene, Gyeongsan, Korea) to extract total RNA.

\section{RNA extraction and cDNA synthesis}

Horse skeletal muscle tissue ( 50 to $100 \mathrm{~g}$ ) was crushed using a mortar, and ground muscle tissue was then dissolved using $1 \mathrm{~mL}$ TRIzol (Invitrogen, Karlsruhe, Germany). Next, $200 \mu \mathrm{L}$ of chloroform was added to remove cells from the organic solvent, the mixture was shaken for $10 \mathrm{~s}$, maintained at $4^{\circ} \mathrm{C}$ for $5 \mathrm{~min}$, and centrifuged at $4^{\circ} \mathrm{C}$ for $15 \mathrm{~min}$. The supernatant was removed and added to a new test tube, mixed with an equal amount of isopropanol, and maintained at $4^{\circ} \mathrm{C}$ for 15 min to collect RNA pellets. Isopropanol was removed from the solution via centrifugation at $4^{\circ} \mathrm{C}$ for $15 \mathrm{~min}$, and the sample was then sterilized with $85 \%$ ethanol and dissolved in RNase-free water. The purity of the extracted RNA was confirmed by measuring absorbance at $230 \mathrm{~nm}$ and $260 \mathrm{~nm}$ using a spectrophotometer (ND-100, Nanodrop Technologies Inc., Wilmington, DE, USA), and only RNA samples with purity (optical density value of $230 \mathrm{~nm} / 260 \mathrm{~nm}$ ) measurements greater than 1.8 were selected and stored at $-70^{\circ} \mathrm{C}$ until the experiment was carried out.

To synthesize cDNA, $1 \mu \mathrm{g}$ of RNA and $1 \mu \mathrm{L}$ each of oligo$\mathrm{dT}$ (Invitrogen, USA) and RNase-free water were added. RNA was denatured at $80^{\circ} \mathrm{C}$ for $3 \mathrm{~min}$, and $\mathrm{CDNA}$ was synthesized using $4 \mu \mathrm{L}$ of $5 \times \mathrm{RT}$ (reverse transcription) buffer, $5 \mu \mathrm{L}$ of 2 $\mathrm{mM}$ dNTPs, $0.5 \mu \mathrm{L}$ of RNase inhibitor (Promega, Madison, WI, USA), and $1 \mu \mathrm{L}$ of moloney-murine leukemia virus RT 
(Promega, USA).

\section{RT-PCR and real time-qPCR}

NCBI (http://www.ncbi.nlm.nih.gov) and the Ensembl Genome Browser (www.ensembl.org) were utilized to retrieve gene sequence information. The primers for amplification of myokines and myogenic marker mRNA (Table 1) were synthesized using PRIMER3 software (http://bioinfo.ut.ee/ primer3-0.4.0/). Reverse transcriptase-PCR and real-time qPCR reactions were carried out in a $25 \mu \mathrm{L}$ reaction solution using a C1000 Thermal Cycler (Bio Rad, Hercules, CA, USA) to measure the relevant expression of target genes. The solution was prepared as follows: $2 \mu \mathrm{L}$ diluted cDNA $(50 \mathrm{ng} / \mu \mathrm{L})$ was added to $14 \mu \mathrm{L}$ SYBR green master mix (Bio Rad, USA) and $1 \mu \mathrm{L}$ each of $5 \mathrm{pmol} / \mu \mathrm{L}$ diluted forward and reverse primers. The conditions used for the real-time qPCR were as follows: initial denaturation at $94^{\circ} \mathrm{C}$ for 10 mins followed by 40 cycles of denaturation at $94^{\circ} \mathrm{C}$ for $10 \mathrm{~s}$, annealing at $60^{\circ} \mathrm{C}$ for $10 \mathrm{~s}$, and extension at $72^{\circ} \mathrm{C}$ for $30 \mathrm{~s}$. All measurements were carried out in triplicate for each specimen, and the $2^{-\Delta \Delta C t}$ method was used to determine relative gene expression. The relative expression of target genes was normalized with glyceraldehyde-3-phosphate dehydrogenase.

\section{MTT assay}

Cell viability was assayed by measuring blue formazan that was metabolized from 3-(4,5-dimethylthiazol-2-yl)-2,5-diphenyl- tetrazolium bromide (MTT) by mitochondrial dehydrogenase. Horse muscle cells were re-suspended in the medium one day before $\mathrm{H}_{2} \mathrm{O}_{2}$ (Junsei, Japan) treatment, at a density of $2 \times 10^{5}$ cells per well in 24 -well culture plates. Liquid medium was replaced with fresh medium containing dimethyl sulfoxide (DMSO) for control. Horse muscle cells were incubated with various concentrations of $\mathrm{H}_{2} \mathrm{O}_{2}$. MTT $(5 \mathrm{mg} / \mathrm{mL})$ was added to each well and incubated for $4 \mathrm{~h}$ at $37^{\circ} \mathrm{C}$. The formazan product formed was dissolved by adding $200 \mu \mathrm{L}$ DMSO to each well, and the absorbance was measured at $570 \mathrm{~nm}$ on an Ultra Multifunctional Microplate Reader (TECAN, Durham, NC, USA). All measurements were performed in triplicate and repeated at least three times.

\section{Statistical analysis}

Means and standard deviations of gene expression were calculated using Microsoft Excel. The statistical significance ${ }^{\star} \mathrm{p}<0.05,{ }^{* *} \mathrm{p}<0.01$, or $\left.{ }^{* *} \mathrm{p}<0.001\right)$ was assessed using an analysis of variance, followed by an unpaired sample t-test using the Prism 5 program (San Diego, CA, USA).

\section{RESULTS}

\section{Expression of exercise-related myokines before and} after exercise in horses

To examine the expression patterns of horse myokines including $I L-6, I L-8, C X C L 2$, and CCL4 after exercise, mRNA

Table 1. List of primers for myokine and myogenic marker detection

\begin{tabular}{|c|c|c|c|c|}
\hline Gene & Accession number & Sequence $\left(5^{\prime}\right.$ to $\left.3^{\prime}\right)$ & Annealing $\operatorname{Tm}\left({ }^{\circ} \mathrm{C}\right)$ & Product size (bp) \\
\hline \multirow[t]{2}{*}{ IL-6 } & NM_001082496.2 & Forward: CACCACTGGTCTTTCGGAGT & 60 & 156 \\
\hline & & Reverse:TCAGGGGTGGTTACTTCTGG & & \\
\hline IL-8 & & Reverse: TCTGAGTTTTCGCAGTGTGG & & \\
\hline \multirow[t]{2}{*}{$C X C L 2$} & NM_001143955.1 & Forward: CAAGAACATCCAGAGCGTGA & 60 & 154 \\
\hline & & Reverse: GCTGCCCTTCTTTAGCATCTT & & \\
\hline \multirow[t]{2}{*}{ MyoD } & NM_001317253.1 & Forward: GACGGCATGATGGACTACAG & 63 & 171 \\
\hline & & Reverse: GGGACTCTCGGTGGAGATG & & \\
\hline \multirow[t]{2}{*}{ PAX7 } & NM_001317254.1 & Forward: CTATCAGGAGACGGGGTCCA & 60 & 434 \\
\hline & & Reverse: GTGTCACAGCATTAGCCTCCT & & \\
\hline Myf5 & NM_001302119.1 & Forward: TTTCGGGGACGAGTTTGAGC & 60 & 445 \\
\hline FHL1 & & Reverse: GAGGAGCTGCTAAGCTTCGAT & & \\
\hline \multirow[t]{2}{*}{ NFATC1 } & XM_02364022.1 & Forward: TTGGTGGTTGAGATACCGCC & 60 & 351 \\
\hline & & Reverse: AGAAAGGTCGTGGAGCTTCG & & \\
\hline \multirow[t]{2}{*}{ GAPDH } & NM_001163856.1 & Forward: GGTGAAGGTCGGAGTAAACG & 60 & 106 \\
\hline & & Reverse:AATGAAGGGGTCATTGATGG & & \\
\hline
\end{tabular}

IL-6, interleukin-6; IL-8, interleukin-8; CXCL2, chemokine (C-X-C motif) ligand 2; CCL4, chemokine (C-C motif) ligand 4; MyoD, myoblast determination protein; PAX7, paired box 7; Myf5, yogenic factor 5; MyoG, myogenin; FHL1, four and a half LIM domains 1; NFATC1, nuclear factor of activated T cells 1; GAPDH, glyceraldehyde-3-phosphate dehydrogenase. 
levels were quantified in muscle tissues from Thoroughbred horses following one bout of trotting on the treadmill. Expression of myokines was significantly increased after exercise in Thoroughbreds ( ${ }^{* *} p<0.001$, Figure 1A). Similar expression patterns were observed in the muscles of Korean native Jeju horses, demonstrating that regulation of myokine expression by exercise is conserved in horses (Figure 1B).

\section{Culture and validation of primary skeletal muscle cells of horse}

We isolated and cultured muscle cells from the skeletal muscle tissue of a neonatal Thoroughbred to establish a reliable system that allowed an in vitro study in horses. Horse muscle cells were stably maintained even after passage 23 in Medium 199 supplemented with $10 \% \mathrm{FBS}$ and $2 \% \mathrm{DES}$. It is interesting to note that horse muscle cells were larger than those of mouse muscle cell line $\mathrm{C} 2 \mathrm{C} 12$. To test whether horse primary myoblast cells possess the capacity for differentiation into myotube cells, horse muscle cells with $80 \%$ confluence were cultured in Medium 199 supplemented with 2\% FBS for 12 days. Dur- ing myogenic differentiation, myoblasts were fused into multinucleated fibers (Figure 2A). Subsequently, we conducted RT-PCR for $M y o D$ (one of the myogenic markers) expression to confirm the origin of the cells. As a result, musclespecific transcription factor $M y o D$ was specifically expressed in both skeletal muscle tissues and cultured cells, but it was not expressed in the other tissues (Figure 2B). RT-PCR analysis for myogenic markers including paired box 7 (PAX7), myogenic factor 5 (Myf5), myogenin $(M y o G)$, four and a half LIM domains 1 (FHL1), and nuclear factor of activated $\mathrm{T}$ cells 1 (NFATc1) confirmed that horse muscle cells maintained myogenic features in vitro (Figure 2C).

\section{Myokine expression in oxidative stress-induced horse muscle cells}

To induce oxidative stress, horse muscle cells were treated with $\mathrm{H}_{2} \mathrm{O}_{2}$ for $6 \mathrm{~h}$ at different concentrations. The effect of oxidative stress with $\mathrm{H}_{2} \mathrm{O}_{2}$ at $200 \mu \mathrm{M}$ to $2 \mathrm{mM}$ on cell viability of horse muscle cells was assessed by the MTT assay. $\mathrm{H}_{2} \mathrm{O}_{2}$ at 2 $\mathrm{mM}$ reduced cell viability by approximately $60 \%$ compared
(A)

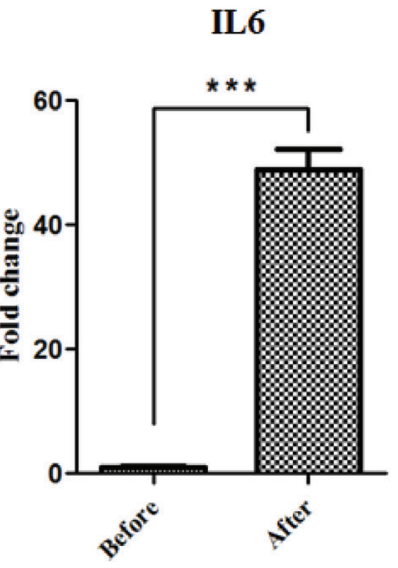

(B)

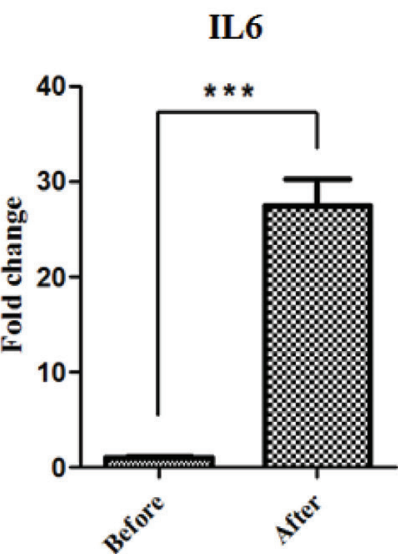

IL8

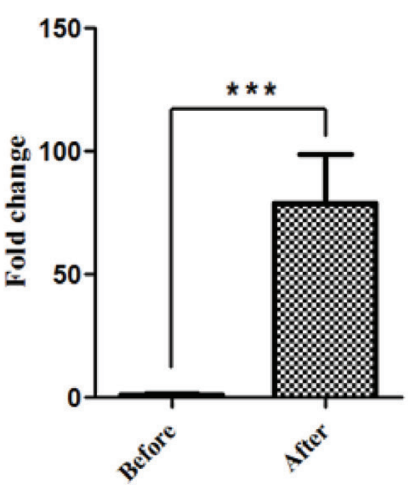

IL8

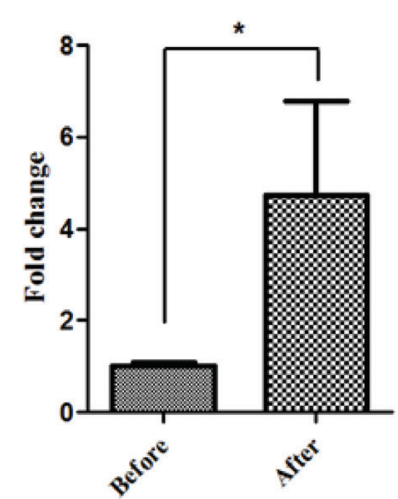

CXCL2

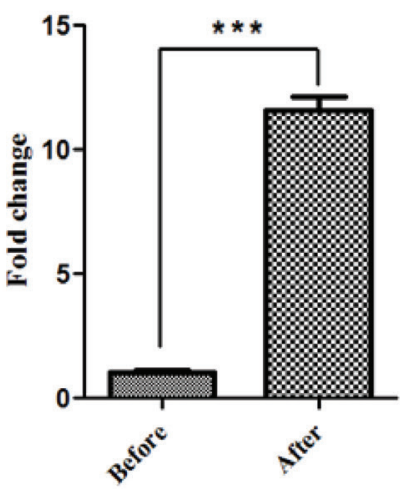

CXCL2

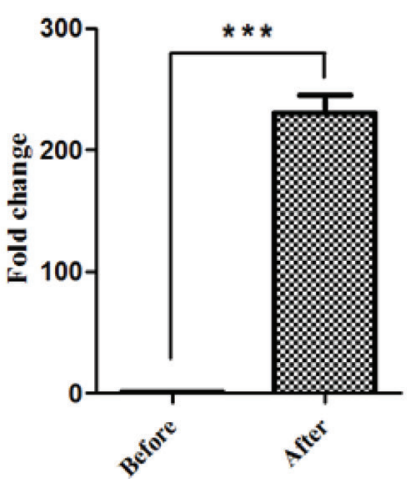

CCL4

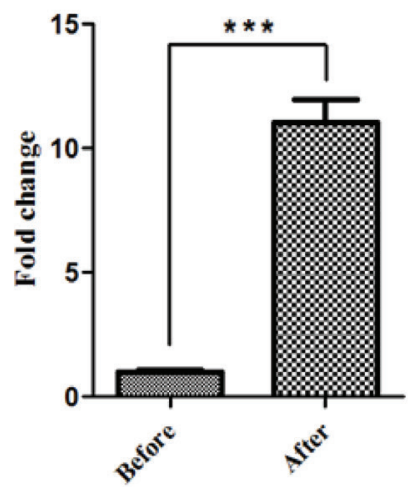

CCL4

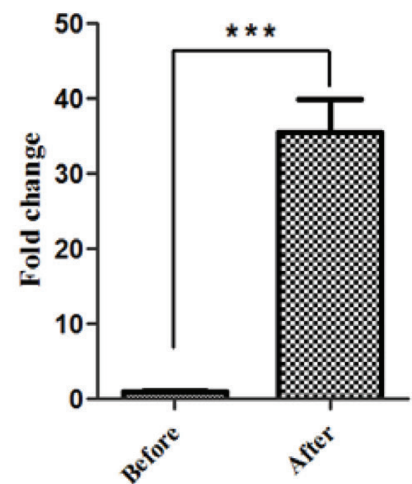

Figure 1. The effect of exercise on myokine expression in the horse skeletal muscle tissue. Expression of myokines (IL-6, IL-8, CXCL2, and CCL4) before and after exercise in Thoroughbred (A) and Jeju (B) horses was identified by quantitative PCR. The results were normalized to glyceraldehyde-3-phosphate dehydrogenase. Error bars represent standard deviation $(n=3),{ }^{*} p<0.05,{ }^{* *} p<0.001$. IL6, interleukin 6; IL8, interleukin 8; CXCL2, (C-X-C motif) ligand 2; CCL4, (C-C motif) ligand 4; PCR, polymerase chain reaction. 
(A)
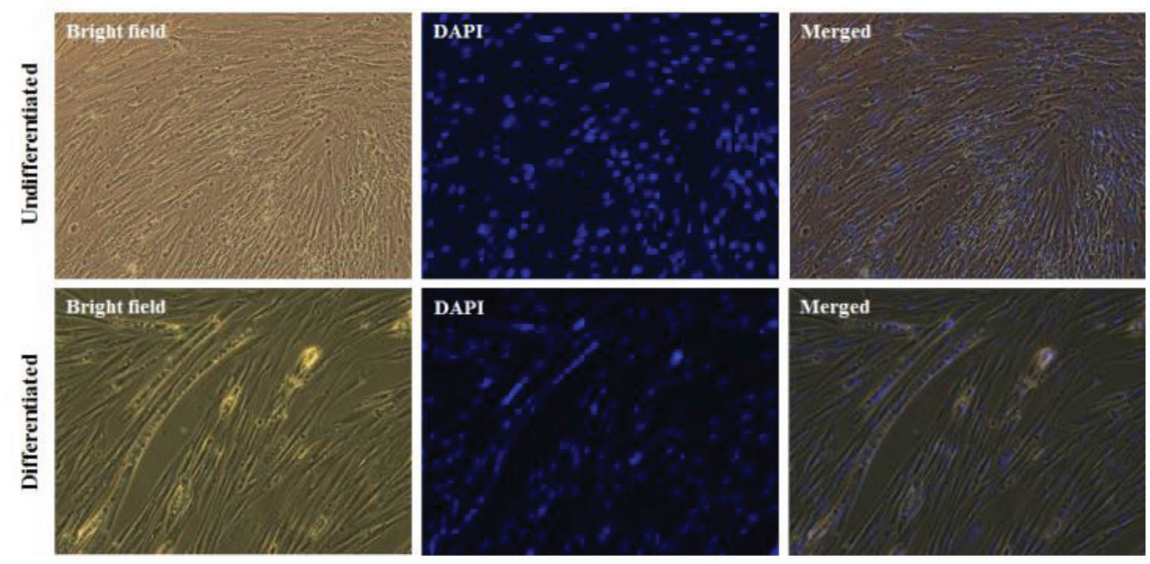

(C)

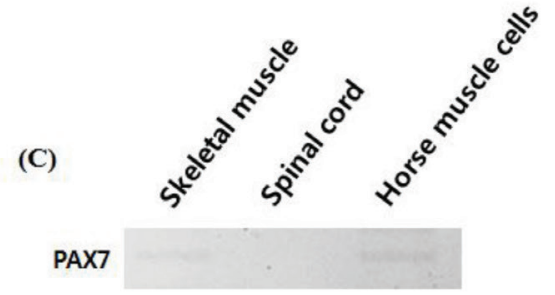

(B)
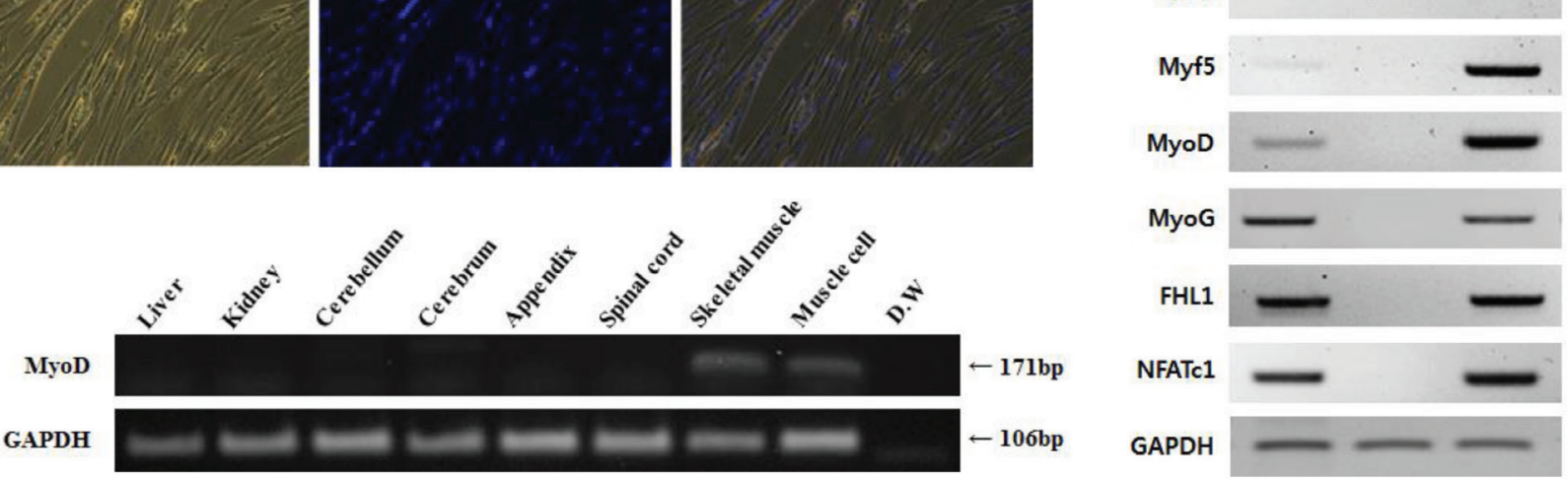

Figure 2. Characterization of horse skeletal muscle cells with myotube formation and myogenic marker expression. (A) Morphology of undifferentiated and differentiated horse skeletal muscle cells (magnification: 200x). Undifferentiated horse muscle cells show mononuclei. Multinuclear cells emerged after culture in differentiated media for 12 days. 4',6-diamidino-2-phenylindole (DAPI) staining was used to determine the nuclei. (B) MyoD expression was identified by RT-PCR in horse tissues including liver, kidney, cerebellum, cerebrum, appendix, spinal cord, skeletal, and horse muscle cells. GAPDH was used as a reference gene. (C) Reverse transcriptase-polymerase chain reaction analysis of myogenic marker expression in the skeletal muscle tissue, spinal cord, and muscle cells of horses. GAPDH was used as a reference gene. MyoD, myoblast determination protein; GAPDH, glyceraldehyde-3-phosphate dehydrogenase; PAX7, paired box 7; Myf5, myogenic factor 5; MyoG, myogenin; FHL1, four and a half LIM domains 1; NFATc1, nuclear factor of activated T cells 1; D.W, distilled water.

to control (Figure 3A). To maximize oxidative stress, horse muscle cells were exposed to $1 \mathrm{mM} \mathrm{H}_{2} \mathrm{O}_{2}$ for $6 \mathrm{~h}$. There were no morphological changes in $\mathrm{H}_{2} \mathrm{O}_{2}$-treated horse muscle cells (Figure $3 \mathrm{~B}$ ). Then, the effects of oxidative stress on the expression of the myokine genes was evaluated by qRT-PCR. Oxidative stress caused by $\mathrm{H}_{2} \mathrm{O}_{2}$ treatment increased the expression of $I L-6\left({ }^{* *} \mathrm{p}<0.01\right), I L-8\left({ }^{*} \mathrm{p}<0.05\right)$, and CXCL2 $\left.{ }^{*} \mathrm{p}<0.05\right) \mathrm{mRNA}$, but CCL4 expression was not altered significantly (Figure 3C).

\section{DISCUSSION}

A variety of cytokines are secreted from muscle cells after exercise $[19,24]$, and this creates a milieu for muscle recovery and inflammatory responses. Although the horse is a representative model for exercise, the expression of exercise-induced cytokines has been poorly studied in horses. Several studies have investigated cytokine expression following exercise [24], and the effects of exercise-induced cytokines in muscles have been observed in previous studies, which found that exercise greatly reduces the risk of chronic inflammatory diseases [25]. Physical activity induces reactive oxygen species (ROS), which initiate signaling cascades and exert various functions [26]. In addition to the expression of oxidative stress-related genes,
ROS are closely related to inflammation induction [26]. Inflammatory cytokines promote the involvement of immune cells such as macrophages or neutrophils [27]. It is assumed that exercise-induced inflammatory responses are required for regenerative and adaptive processes in the skeletal muscle. In this study, we examined the expression of myokines after horse exercise, and $I L-6, I L-8, C X C L 2$, and CCL4 increased after exercise in Thoroughbred and Jeju horses (Figure 1). It has been previously shown that the exercise-induced $I L-6$ has specific roles in fat metabolism and immune system $[16,17]$. Although the exact function of $I L-8, C X C L 2$, and CCL4 in exercise still remains uncertain, the increased expressions after exercise in muscle tissue are similar among species $[11,12,19]$. Therefore, these results indicate that exercise-related myokines may play a role in exercise regardless of species and breed.

In this study, we established a culture system for horse muscle cells derived from the skeletal muscle tissue of a neonatal Thoroughbred (Figure 2A). After 23 culture passages in vitro, we investigated whether these cells possessed the myogenic features by examining myogenic markers using RT-PCR. $P A X 7$ is regarded as an important gene for the specification of myogenic satellite cells [28]. Though $P A X 7$ was expressed weakly in both horse skeletal muscle tissue and horse muscle cells, it was reasonable to assume that $P A X 7$ may play a role in 
(A)

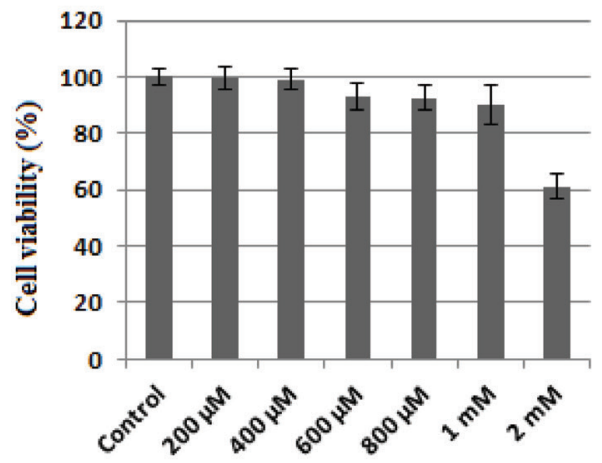

(B)

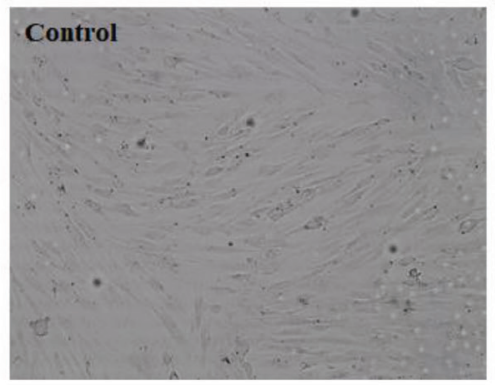

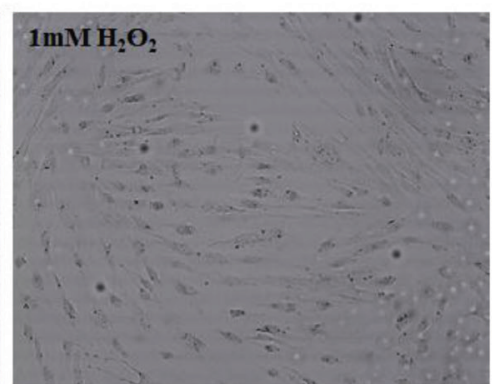

(C)
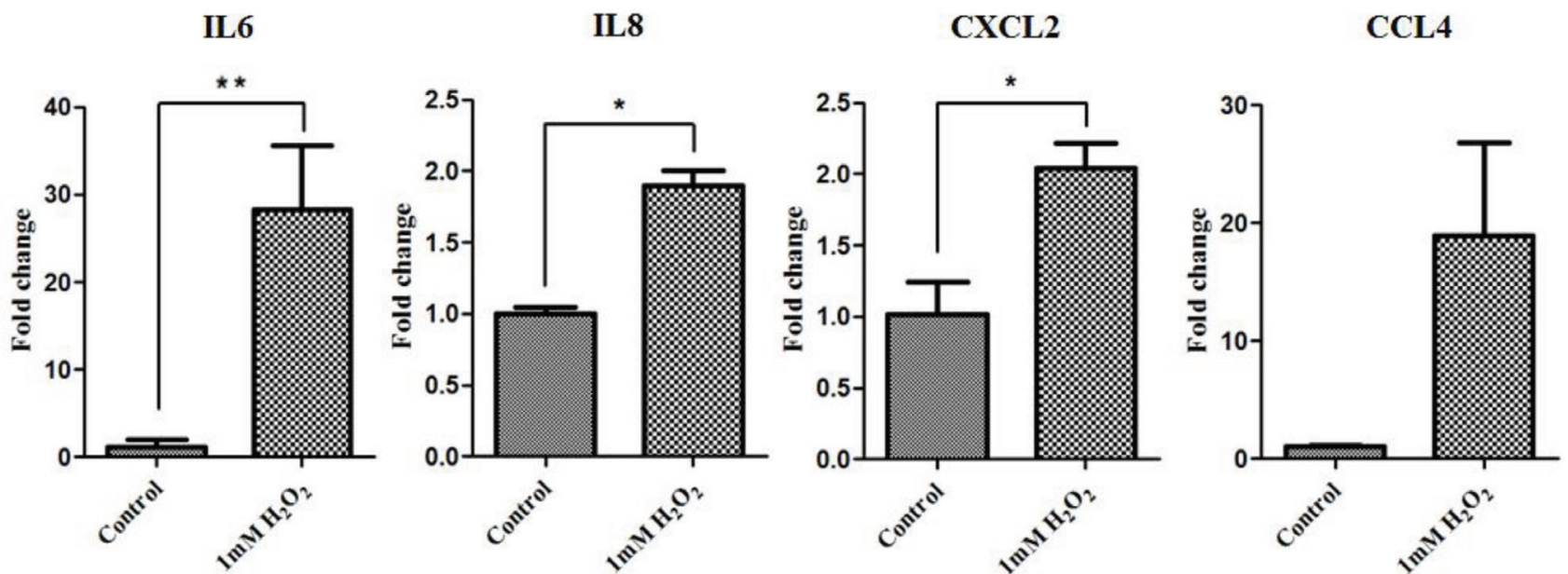

Figure 3. The effect of oxidative stress on myokine expression in the horse muscle cells. (A) MTT assay to measure cell viability in the horse muscle cells after treatment with $\mathrm{H} 2 \mathrm{O} 2$ at different concentrations for $6 \mathrm{~h}$. The $\mathrm{x}$-axis indicates that the concentration of $\mathrm{H}_{2} \mathrm{O}_{2}$. (B) Phenotypic comparison between regular and $1 \mathrm{mM} \mathrm{H}_{2} \mathrm{O}_{2}$-treated horse skeletal muscle cells (magnification: 100x). (C) Expression of myokines (IL-6, IL-8, CXCL2, and CCL4) after $1 \mathrm{mM} \mathrm{H}_{2} \mathrm{O}_{2}$ treatment for $6 \mathrm{~h}$ was identified by quantitative polymerase chain reaction. The results were normalized to GAPDH. Error bars represent standard deviation $(n=3),{ }^{*} p<0.05,{ }^{* *} p<0.01$. IL-6, interleukin 6 ; IL-8, interleukin 8; CXCL2, (C-X-C motif) ligand 2; CCL4, (C-C motif) ligand 4, GAPDH, glyceraldehyde-3-phosphate dehydrogenase.

the specification of myogenic cell lineages in horses. In addition, other myoblast markers, Myf5, MyoD, MyoG, FHL1, and NFATc1, were expressed in horse muscle cells, indicating that the cell population possesses myogenic features observed in other mammals; however, further investigation is required (Figure 2C). Because the cells were derived from neonatal skeletal muscle tissue, they may contain various myogenic cells. Further study is needed to demonstrate the exact state of these horse skeletal muscle-derived cells. Finally, we validated the possibility of a suitable in vitro system for studying horse muscle physiology and exercise-induced muscle disease using in vitro cultured horse muscle cells (Figure 3). Horse muscle cells developed in this study will provide an important system for the functional study of exercise-related genes.

In conclusion, exercise can induce the expression of cytokines, which play an important role in muscle regeneration and anti-inflammation in horse skeletal muscle tissues after exercise. Additionally, we established a horse skeletal muscle cell culture, which will be a valuable tool for investigating the expression and function of exercise-related genes.

\section{CONFLICT OF INTEREST}

We certify that there is no conflict of interest with any financial organization regarding the material discussed in the manuscript.

\section{ACKNOWLEDGMENTS}

This work was supported by a grant from the Next-Generation BioGreen 21 Program (Project No. PJ01325701), the Rural Development Administration, Republic of Korea, and a grant from the Individual Basic Science \& Engineering Research Program (2017R1D1A1B03036432), the National Research Foundation of Korea (NRF), and the Korean government.

\section{REFERENCES}

1. Poole DC. Current concepts of oxygen transport during exercise. Equine Comp Exerc Physiol 2004;1:5-22.

2. Kim H, Lee T, Park W, et al. Peeling back the evolutionary 
layers of molecular mechanisms responsive to exercise-stress in the skeletal muscle of the racing horse. DNA Res 2013;20: 287-98.

3. Park KD, Park J, Ko J, et al. Whole transcriptome analyses of six thoroughbred horses before and after exercise using RNASeq. BMC Genomics 2012;13:473.

4. Capomaccio S, Cappelli K, Barrey E, et al. Microarray analysis after strenuous exercise in peripheral blood mononuclear cells of endurance horses. Anim Genet 2010;41:166-75.

5. Eivers SS, McGivney BA, Fonseca RG, et al. Alterations in oxidative gene expression in equine skeletal muscle following exercise and training. Physiol Genomics 2010;40:83-93.

6. Park JW, Song KD, Kim NY, et al. Molecular analysis of alternative transcripts of equine $\mathrm{AXL}$ receptor tyrosine kinase gene. Asian-Australas J Anim Sci 2017;30:1471-7.

7. Cho HW, Shin S, Park JW, et al. Molecular characterization and expression analysis of the peroxisome proliferator activated receptor delta (PPAR $\delta$ ) gene before and after exercise in horse. Asian-Australas J Anim Sci 2015;28:697-702.

8. Park JW, Choi JY, Hong SA, et al. Exercise induced upregulation of glutamate-cysteine ligase catalytic subunit and glutamatecysteine ligase modifier subunit gene expression in Thoroughbred horses. Asian-Australas J Anim Sci 2017;30:728-35.

9. Pedersen BK, Åkerström TC, Nielsen AR, Fischer CP. Role of myokines in exercise and metabolism. J Appl Physiol 2007; 103:1093-8.

10. Jonsdottir I, Schjerling P, Ostrowski K, et al. Muscle contractions induces interleukin- 6 mRNA production in rat skeletal muscles. J Physiol (Lond) 2000;528:157-63.

11. Akerstrom TC, Steensberg A, Keller P, et al. Exercise induces interleukin-8 expression in human skeletal muscle. J Physiol 2005;563:507-16.

12. Ostrowski K, Rohde T, Asp S, Schjerling P, Pedersen BK. Chemokines are elevated in plasma after strenuous exercise in humans. Eur J Appl Physiol 2001;84:244-5.

13.Peake JM, Roberts LA, Figueiredo VC, et al. The effects of cold water immersion and active recovery on inflammation and cell stress responses in human skeletal muscle after resistance exercise. J Physiol 2017;595:695-711.

14. Croisier JL, Camus G, Venneman I, et al. Effects of training on exercise-induced muscle damage and interleukin 6 production.
Muscle Nerve 1999;22:208-12.

15. Pedersen BK, Steensberg A, Fischer C, et al. The metabolic role of IL-6 produced during exercise: is IL-6 an exercise factor? Proc Nutr Soc 2004;63:263-7.

16. Wolsk E, Mygind H, Grøndahl TS, Pedersen BK, van Hall G. IL-6 selectively stimulates fat metabolism in human skeletal muscle. Am J Physiol Endocrinol Metab 2010;299:E832-40.

17.Steensberg A. The role of IL-6 in exercise-induced immune changes and metabolism. Exerc Immunol Rev 2003;9:40-7.

18. Koch AE, Polverini PJ, Kunkel SL, et al. Interleukin-8 as a macrophage-derived mediator of angiogenesis. Science 1992; 258:1798-801.

19. Catoire M, Mensink M, Kalkhoven E, Schrauwen P, Kersten S. Identification of human exercise-induced myokines using secretome analysis. Physiol Genomics 2014;46:256-67.

20. Bystry RS, Aluvihare V, Welch KA, Kallikourdis M, Betz AG. $\mathrm{B}$ cells and professional APCs recruit regulatory $\mathrm{T}$ cells via CCL4. Nat Immunol 2001;2:1126-32.

21.Zlotnik A, Yoshie O. Chemokines: a new classification system and their role in immunity. Immunity 2000;12:121-7.

22. Yahiaoui L, Gvozdic D, Danialou G, Mack M, Petrof BJ. CC family chemokines directly regulate myoblast responses to skeletal muscle injury. J Physiol 2008;586:3991-4004.

23. Warren GL, O'Farrell L, Summan M, et al. Role of CC chemokines in skeletal muscle functional restoration after injury. Am J Physiol Cell Physiol 2004;286:C1031-6.

24. Pourteymour S, Eckardt K, Holen T, et al. Global mRNA sequencing of human skeletal muscle: search for novel exerciseregulated myokines. Mol Metab 2017;6:352-65.

25. Beavers KM, Brinkley TE, Nicklas BJ. Effect of exercise training on chronic inflammation. Clin Chim Acta 2010;411:785-93.

26. Niess AM, Simon P. Response and adaptation of skeletal muscle to exercise-the role of reactive oxygen species. Front Biosci 2007;12:4826-38.

27. Peake J, Nosaka K, Suzuki K. Characterization of inflammatory responses to eccentric exercise in humans. Exerc Immunol Rev 2005;11:64-85.

28. Seale P, Sabourin LA, Girgis-Gabardo A, et al. Pax7 is required for the specification of myogenic satellite cells. Cell 2000;102: $777-86$ 